Louisiana State University

LSU Digital Commons

Faculty Publications

Department of Geology and Geophysics

$1-1-1994$

\title{
Seven million years of glaciation in Greenland
}

H. C. Larsen

Texas A\&M University

A. D. Saunders

Texas A\&M University

P. D. Clift

Texas A\&M University

J. Beget

Texas A\&M University

W. Wei

Texas A\&M University

See next page for additional authors

Follow this and additional works at: https://digitalcommons.Isu.edu/geo_pubs

\section{Recommended Citation}

Larsen, H., Saunders, A., Clift, P., Beget, J., Wei, W., Spezzaferri, S., Ali, J., Cambray, H., Demant, A., Fitton, G., Fram, M., Fukuma, K., Gieskes, J., Holmes, M., Hunt, J., Lacasse, C., Larsen, L., Lykke-Andersen, H., Meltser, A., Morrison, M., Nemoto, N., Okay, N., Saito, S., Sinton, C., Stax, R., Vallier, T., Vandamme, D., \& Werner, R. (1994). Seven million years of glaciation in Greenland. Science, 264 (5161), 952-955.

https://doi.org/10.1126/science.264.5161.952

This Article is brought to you for free and open access by the Department of Geology and Geophysics at LSU Digital Commons. It has been accepted for inclusion in Faculty Publications by an authorized administrator of LSU Digital Commons. For more information, please contact ir@lsu.edu. 


\section{Authors}

H. C. Larsen, A. D. Saunders, P. D. Clift, J. Beget, W. Wei, S. Spezzaferri, J. Ali, H. Cambray, A. Demant, G. Fitton, M. S. Fram, K. Fukuma, J. Gieskes, M. A. Holmes, J. Hunt, C. Lacasse, L. M. Larsen, H. LykkeAndersen, A. Meltser, M. L. Morrison, N. Nemoto, N. Okay, S. Saito, C. Sinton, R. Stax, T. L. Vallier, D. Vandamme, and R. Werner 
University of Nebraska - Lincoln

DigitalCommons@University of Nebraska - Lincoln

Papers in the Earth and Atmospheric Sciences Earth and Atmospheric Sciences, Department

5-13-1994

\section{Seven Million Years of Glaciation in Greenland}

H. C. Larsen

Texas A\&M University Research Park

A. D. Saunders

Texas A\&M University

P. D. Clift

Texas A\&M University

J. Beget

Texas A\&M University

W. Wei

Texas A\&M University

See next page for additional authors

Follow this and additional works at: https://digitalcommons.unl.edu/geosciencefacpub

Part of the Earth Sciences Commons

Larsen, H. C.; Saunders, A. D.; Clift, P. D.; Beget, J.; Wei, W.; Spezzaferri, S.; Ali, J.; Cambray, H.; Demant, A.; Fitton, G.; Fram, M. S.; Fukuma, K.; Gieskes, J.; Holmes, Mary Anne; Hunt, J.; Lacasse, C.; Larsen, L. M.; Lykke-Andersen, H.; Meltser, A.; Morrison, M. L.; Nemoto, N.; Okay, N.; Saito, S.; Sinton, C.; Stax, R.; Vallier, T. L.; Vandamme, D.; and Werner, R., "Seven Million Years of Glaciation in Greenland" (1994). Papers in the Earth and Atmospheric Sciences. 55.

https://digitalcommons.unl.edu/geosciencefacpub/55

This Article is brought to you for free and open access by the Earth and Atmospheric Sciences, Department of at DigitalCommons@University of Nebraska - Lincoln. It has been accepted for inclusion in Papers in the Earth and Atmospheric Sciences by an authorized administrator of DigitalCommons@University of Nebraska - Lincoln. 


\section{Authors}

H. C. Larsen, A. D. Saunders, P. D. Clift, J. Beget, W. Wei, S. Spezzaferri, J. Ali, H. Cambray, A. Demant, G. Fitton, M. S. Fram, K. Fukuma, J. Gieskes, Mary Anne Holmes, J. Hunt, C. Lacasse, L. M. Larsen, H. LykkeAndersen, A. Meltser, M. L. Morrison, N. Nemoto, N. Okay, S. Saito, C. Sinton, R. Stax, T. L. Vallier, D.

Vandamme, and R. Werner 
Published in Science, New Series, Vol. 264, No. 5161 (May 13, 1994), pp. 952-955.

Copyright (C) 1994 American Association for the Advancement of Science. Used by permission.

Supported by the members of the Ocean Drilling Program, an international scientific consortium.

The seismic data were funded by the Danish Natural Research Council.

\title{
Seven Million Years of Glaciation in Greenland
}

\author{
H. C. Larsen, A. D. Saunders, P. D. Clift, J. Begét,W.Wei, S. Spezzaferri, J.Ali, H. Cambray, A. Demant, G. Fitton, \\ M. S. Fram, K. Fukuma, J. Gieskes, M. A. Holmes, J. Hunt, C. Lacasse, L. M. Larsen, H. Lykke-Andersen, A. Meltser, \\ M. L. Morrison, N. Nemoto, N. Okay, S. Saito, C. Sinton, R. Stax, T. L.Vallier, D.Vandamme, and R.Werner \\ (The ODP Leg 152 Scientific Party)
}

\author{
Ocean Drilling Program, Science Operations, Texas A\&M University Research Park, 1000 Discovery Drive, College Station, TX 776459547, USA. \\ Corresponding author - P. D. Clift
}

\section{Abstract}

Glacial till, glaciomarine diamictites, and ice-rafted detritus found in marine cores collected off the shore of southeast Greenland record multiple Late Cenozoic glaciations beginning in the Late Miocene. Distinct rock assemblages and seismic stratigraphic control correlate the diamictites with glaciation of the southeast Greenland margin. Glaciers advanced to the sea during several intervals in the Pliocene and Pleistocene. North Atlantic glaciation may have nucleated in southern Greenland rather than further north because of the high mountains and the high levels of precipitation in this region.

The Greenland Ice Sheet (GIS) is the only continental ice sheet in the Northern Hemisphere in the present interglacial period, but little is known about when it formed or its long-term history. Ice cores from the GIS show that an ice sheet was present during the last 200,000 years (1). Glacial sediments at two localities on Greenland are thought to have been deposited during latest Pliocene time, 1.8 to 2.0 million years ago (Ma) (2, $3)$. The earliest firm evidence of glaciation in the North Atlantic area has been from Iceland. There, glacial sediments date from 3.1 Ma (4), but glaciers there may not have grown large enough to reach the sea until 2.0 Ma (5). The earliest occurrence of abundant ice-rafted detritus (IRD) found widely in North Atlantic marine cores dates to about 2.4 Ma (6-8), but it is not known if ice sheets on Greenland were a source for this debris or if glaciers existed on Greenland at even earlier times. Low concentrations of fine-grain IRD have been reported from marine cores off mid-Norway and suggest that some North Atlantic glaciation could date back as early as $5.45 \mathrm{Ma}(8)$. However, it has also been suggested that before $2.4 \mathrm{Ma}$, any glaciers in the North Atlantic area were too small to reach the sea (5). Hence. there is considerable uncertainty with regard to the location and timing of early glaciation within the North Atlantic.

During Ocean Drilling Program (ODP) Leg 152, a transect of six sites (ODP sites 914 to 919) was drilled, extending from 40 to $185 \mathrm{~km}$ east of the southeast coast of Greenland (Figure 1). Four sites (sites 914 to 917) were lo- cated on the continental shelf in a 500-mdeep trough, and two deep-water sites (sites 918 and 919) were located below the shelf break, 40 and $115 \mathrm{~km}$ seaward of the mouth of the trough, respectively. All sites are within the present-day limit of icebergs from the highly productive southeast Greenland coast (9). These marine cores contain an unusually complete record of glaciations of southeast Greenland (Figure 2). The data show that substantial glaciation in Greenland began as early as $7 \mathrm{Ma}$ in the Late Miocene following a relatively mild climate during the Middle Miocene.

The most complete record of Miocene and Pliocene glaciations was obtained at ODP site 918, drilled in $1800 \mathrm{~m}$ of water $110 \mathrm{~km}$ from the coast of Greenland (Figures 1 and 2). The upper $550 \mathrm{~m}$ of sediment at the 1310-m-deep site 918 contains abundant silts and muds, within which numerous, typically granule- to pebble-size gravel clasts, but also occasionally cobble- to even bouldersize clasts. are suspended. In addition, a number of more massive, $0.3-$ to 10.0 $\mathrm{m}$-thick beds of poorly sorted, ungraded silt, sand, and angular gravel are present (Figure 2). The two types of sediments are interpreted as follows: (i) hemipelagic sediment and turbidites with discrete occurrences both of more fine grain IRD and larger dropstones and (ii) more massive glaciomarine diamictons. Both sediment types, therefore, reflect glacial, although variable, conditions within the source area. Indeed, intervals up to $40 \mathrm{~m}$ thick without macroscopic IRD exist in cores from site 918. The diamictons show

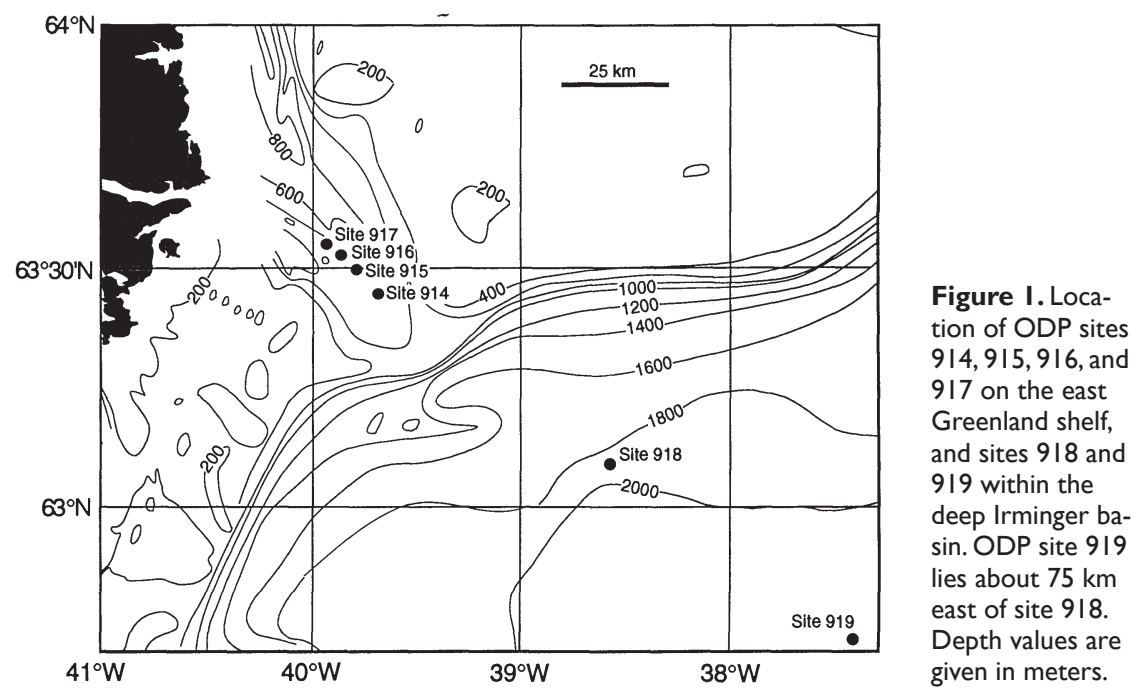


relatively high magnetic susceptibility and high bulk density relative to the intercalated marine sediments. Some of these layers may be correlative with the extensive Heinrich layers of glaciomarine sediment described elsewhere in the North Atlantic, but most of the diamictite horizons are older than any previously recognized Heinrich layers (10).

The IRD and dropstones were present in situ, in places actually cored through, in undisturbed sediment cores for which the possibility of down-hole contamination with clasts can be excluded. The possibility exists, however, that dropstones were transported within mass flows from unstable accumulations of glacial sediments of the shelf/slope region and into their present-day, deep-basin plain setting, although this is much more likely to occur in a direct-slope setting (11). The fine-grain nature of the matrix - the lack of thick or

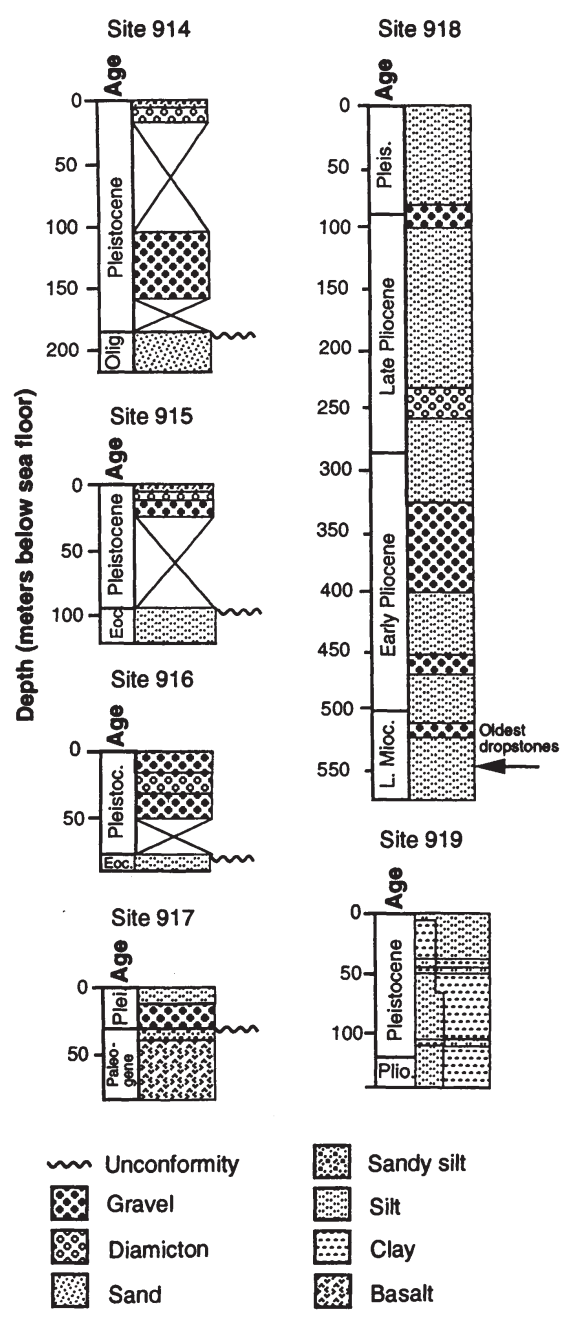

Figure 2. Simplified logs showing the Late Miocene to recent sediments deposited at each ODP drill site. Note the erosive base to the sections at sites 914 to 917 and the expanded section at site 918 . The short section at site 919 reflects a lack of deep drilling at that site. graded beds (or both) and the lack of distorted sediment structures or strong erosive bases - is not in support of mass flows generally capable of transporting the large clasts observed. This condition would also be inconsistent with the often close association of dropstones and finely structured patches of sandy to granule-size IRD.

The composition of the ice-rafted material reflects a provenance from rocks exposed along the coast of southeast and central east Greenland and allows the deep-sea record of alternating glaciomarine and marine sedimentation to be correlated with the growth and wastage of glaciers on the nearby coast. At least $50 \%$ of the gravel clasts in each diamictite consist of gneiss and granite from the Precambrian basement terrain of southeastern Greenland $(12,13)$. Basalt clasts are also abundant and were likely derived from thick Tertiary basalts exposed on the inner shelf and along the coast to the north $(14,15)$. Other less frequently encountered lithologies include schist, limestone, and sandstone, which were probably transported from the fjord zone of northeastern Greenland (16). The matrix of the diamictites consists of highly permeable, clay- to fine sand-size, quartz-rich rock flour and evidently was derived from glacial comminution of felsic high-grade basement rocks. Modern IRD from east Greenland has similar characteristics (17). Polar sea ice seasonally drifts southward through the study region but cannot be a source for the dominating clast assemblages. Because only limited amounts of sea ice form in the defined source region, we interpret the IRD and dropstones as mainly iceberg-transported.

The easternmost site, ODP site 919, was drilled $75 \mathrm{~km}$ seaward of site 918 in $2000 \mathrm{~m}$ of water (Figure 1). This hole was only $145 \mathrm{~m}$ deep and recovered silts and muds with a lower abundance of IRD and dropstones than at the more proximal site 918 (Figure 2). The ODP sites 914, 915, 916, and 917 were drilled on the con-

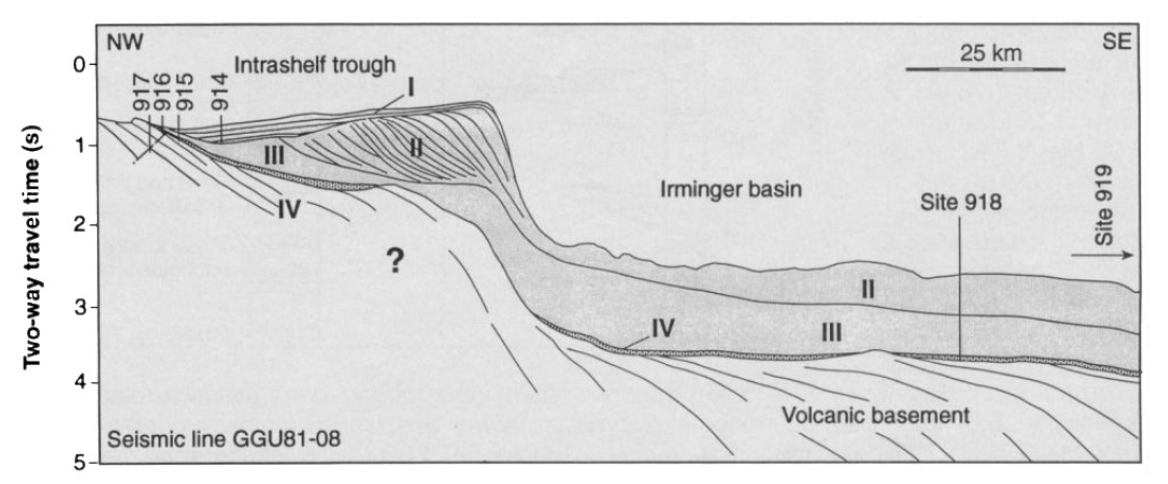

Figure 3. Interpretation of seismic profile through glacial sediments on the east Greenland shelf and in the deep sea (I6). Seismic Unit I: Pleistocene; Unit II : Late Miocene to Pleistocene; Unit III: Oligocene to early Late Miocene; Unit IV: Eocene.

tinental shelf, only 40 to $75 \mathrm{~km}$ from the Greenland coast (Figure 1). Cores from these sites recovered glaciomarine sediments intercalated with a strongly compacted glacial till, characterized by high shear strength measured in the shipboard physical properties laboratory to $150 \mathrm{kPa}$ with the use of a motorized shear vane device. The till was evidently deposited and deformed below grounded shelf ice during a past advance of the GIS that extended at least $75 \mathrm{~km}$ onto the continental shelf, including areas where presentday water depth exceeds $500 \mathrm{~m}$. The till contains a clast assemblage with a lower proportion of basaltic material than at site 918, indicating a smaller contribution of IRD from basalt outcrops to the north. Seismic stratigraphic unconformities within the glacial shelf section were not observed in the cores because of low recovery and poor stratigraphic control within the glacial shelf sediments.

The seismic data correlate the distal diamictites at ODP site 918 with the proximal glacial deposits on the shelf (Figure 3). The data show that the outer continental shelf for the main part is constructed of a stack of shingled, seaward-dipping beds (Unit II in Figure 3). Landward and upward, this package can be traced into a subhorizontally bedded package (Unit I) that is coeval to younger sediment, comprising glaciomarine sediments and till (Figures 2 \& 3). During past advances of the GIS onto the shelf, debris from the continent, together with material reworked from below the glacier, was transported seaward and deposited as part of a large-scale progradational glacial fan (Unit II) at the shelf edge (18). Likewise, during ice recession, primarily vertical aggradation took place (Unit I).

The lowest occurrence of a diamictite and dropstones at site 918 is at $543.5 \mathrm{~m}$ below the sea floor (mbsf), where a 30 $\mathrm{cm}$-thick zone of IRD contains gravelsize clasts of Greenlandic gneiss and basalt in a sandy matrix (Figure 4). Below this diamicton is a transitional, 60- 
$\mathrm{m}$-thick zone in which the percentage of $\mathrm{CaCO}_{3}$ drops up-section from $40 \%$ to less than $10 \%$. In the North Atlantic, this value is largely controlled by the influx of ice-rafted, non-carbonate debris (6-8, $19,20)$. The underlying carbonate-rich sediments contain evidence of a fairly warm-water environment, as determined from the planktonic microfauna. Microscope smear slides show an increasing abundance of quartz and other silicate minerals upward through the transition zone and a decreasing abundance of nannofossils and foraminifers. Furthermore, a large increase in the average sedimentation rate takes place within the upper $500 \mathrm{~m}$ of sediments at site 918 (Figure 4), suggesting considerable glacial erosion of the source area.

The $60-\mathrm{m}$ transition zone below the diamicton at $543.5 \mathrm{~m}$ is interpreted as reflecting climatic cooling leading to increased erosion and shedding of clastic detritus from southern Greenland into the adjacent deep sea. The lowering of the carbonate content in the sediment may also reflect increased carbonate dissolution by lower water temperatures, although strongly reduced biogenic productivity because of extensive sea-ice cover is unlikely.

The diamicton at $543.5 \mathrm{~m}$ is interpreted as reflecting full glaciation of at least the southeast Greenland region, with glaciers extending to coastline or beyond and with the production of icebergs at a similar (or higher) level than at present. Mountain glaciers may have formed well before this diamicton, but possible IRD below $543.5 \mathrm{~m}$ was not evident from the shipboard analysis of the core. Core recovery was not continuous at site 918, but the Brunhes and Matuyama chrons and the Olduvai and Reunion events were recognized in the upper part of the drill hole (Figure 4). Although the transition between the Matuyama and Gauss chrons was not recovered, normally magnetized sediments found below $385 \mathrm{mbsf}$ were likely deposited during the Gauss chron (>2.6 Ma).

Microfossils provide a more accurate date on the lowest glaciomarine sediment at 543.5 mbsf (Figure 4), with ages derived from bio- and magnetostratigraphic studies of high- to middle-latitude sites $(21,22)$. Above 543 mbsf, sediments contain the nannofossil Discoaster quinqueramus at $513 \mathrm{mbsf}$, a species that became extinct before $5.5 \mathrm{Ma}(21)$, as well as the transition from dominantly dextral to dominantly sinistral coiling in the planktonic foraminifer Neogloboquadrina atlantica, an event dated to $6.6 \mathrm{Ma}$ (22). Below the glaciomarine sediments, the lowest occurrence of Neogloboquadrina acostaensis, at $628 \mathrm{mbsf}$, indicates an age of $10.7 \mathrm{Ma}$. If a linear sedimentation rate is assumed between these biochronologic control points (Figure 4), the age of the earliest glaciomarine sediment at $543 \mathrm{mbsf}$ is $7.0 \mathrm{Ma}$, and the marked drop in $\mathrm{CaCO}_{3}$ at $600 \mathrm{mbsf}$ is dated at 9.6 Ma. The sequence cored between 543 and 490 mbsf contains dropstones and diamictites throughout. This record indicates that Greenland glaciers continued to extend to the sea and discharge icebergs for perhaps a million years after the deposition of the lowest diamictite layer.

The greatest concentration of diamictite layers is in a 70-m-thick package, including one deposit $10 \mathrm{~m}$ thick, from 100 to $170 \mathrm{~m}$ below the Reunion event of the Matuyama chron (approximately 2.21 $\mathrm{Ma}$ ) and 70 to $140 \mathrm{~m}$ above sediments assigned to the Gauss chron (>2.6 Ma) (Figure 4). One or more of the diamictite layers within this interval may correlate with the horizon of IRD found widely across the North Atlantic and dated at 2.4 to $2.5 \mathrm{Ma}(6-8)$.
Thus, Greenland could have been the source of much of the IRD distributed across the North Atlantic at this time. However, the volume of dropstones and IRD with coarse or larger sand size found at the easternmost site 919 (Figure 2 ) is less than $10 \%$ of that at site 918 . The eastward decrease in glacial sedimentation recorded in the distal, offshore sites suggests that, as at present, a strong eastwest climatic gradient existed and ice was mainly transported south. Although severe down-hole contamination problems exist in the cores of ODP site 646 south of Greenland, these cores are consistent with a Late Miocene glaciation of southern Greenland (23).

The glacially influenced deposits off east Greenland are separated by marine sediments completely free of dropstones or diamictites (Figure 4), which apparently correspond to times when glaciers onshore Greenland retreated from coastal areas or perhaps disappeared entirely. These variations in the Pliocene climate may correspond to interglacial periods observed in the benthic foraminifera1 $\partial^{18} \mathrm{O}$ record, and whose maxima are dated to 3.1, 2.7, 2.6, and 2.4 Ma (24). Likewise, one or more of the apparent ice-free intervals in the Late Pliocene may correlate with an interval when warm conditions and Boreal forests prevailed in Greenland $(25,26)$.

Several lines of evidence suggest that globally significant climate perturbations generated glaciers in other parts of the Earth at about the same time glaciation began in the North Atlantic area on Greenland. Isotope data from marine benthic foraminifers record an increase of about 9.13 per mil in the $\partial^{18} \mathrm{O}$ record of the oceans at 6 to $7 \mathrm{Ma}$. This increase has been thought to indicate the growth of ice caps and small ice sheets $(27,28)$. Global sea-level reconstructions show a regression occurring at the same

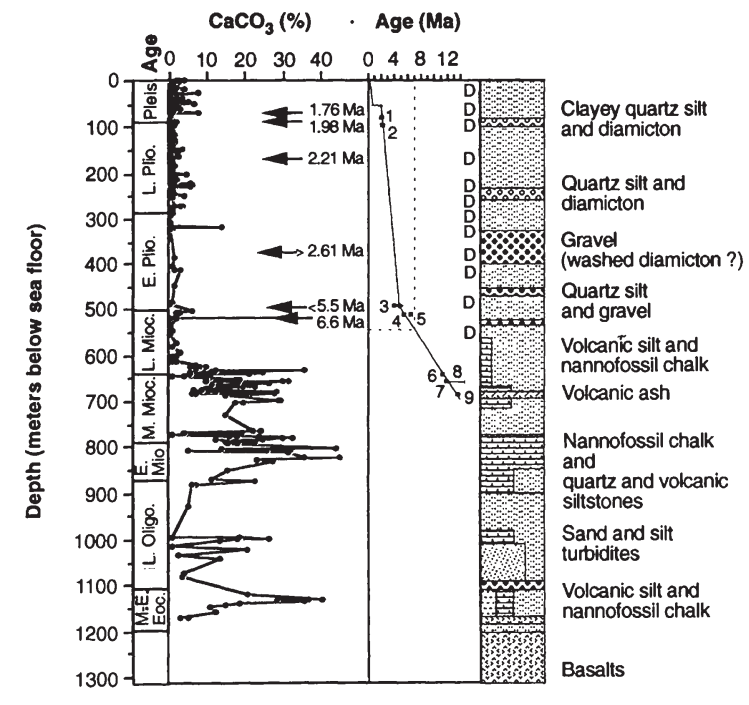

Figure 4. Schematic sedimentary log of the section cored at site 918 showing diamictite layers (marked as "D"). The percentage of $\mathrm{CaCO}_{3}$ in sediments shows a marked drop at $600 \mathrm{mbsf}$, corresponding to the first influence of glacial sedimentation. Sedimentation rate estimates are based on magnetic and biochronologic datums, including: I, top of Olduvai chron, I.76 Ma; 2, base of Olduvai chron, I.98 Ma; 3, last occurrence (LO) of Reticulofenestra gelida (nannofossil), 3.65 Ma; 4, LO Discoaster quinqueramus (nannofossil), $5.5 \mathrm{Ma} ; 5$, coiling change from dominantly dextral to dominantly sinistral coiled morphotypes of Neogloboquadrina atlantica (planktonic foraminifer), 6.6 Ma; 6, first occurrence of Neogloboquadrina acostaensis (planktonic foraminifer), I0.7 Ma; 7, LO of Cyclicargolithus floridanus (nannofossil), II.9 Ma; 8 , stratigraphic range of Globorotalia praemenardii (planktonic foraminifer), I2.0 to I4.5 Ma; 9, LO of Sphenolithus heteromorphus (nannofossil), I $3.6 \mathrm{Ma}$. With assumed linear sedimentation rates, the lowest glaciomarine diamictite dates to $7 \mathrm{Ma}$, while the $\mathrm{CaCO}_{3}$ drop in the sediments occurred at about $9.6 \mathrm{Ma}$. 
time $(29,30)$. Given that the ocean $\partial^{18} \mathrm{O}$ value changes by 0.11 per mil per $10 \mathrm{~m}$ of sea-level change (31), as much as a 12$m$ drop in sea level may have occurred at this time. In comparison, the GIS now contains about a $2.5 \times 10^{6} \mathrm{~km}^{3}$ water equivalent, corresponding to a 5 - to 7 -m change in sea level. Significant glaciation occurred from the Late Miocene in southeast Alaska, where more than 5 $\mathrm{km}$ of glaciomarine sediments have been deposited since about 6.5 Ma (32). Ocean water also cooled at about 6.3 Ma in the northwest Pacific (33). In the Southern Hemisphere, ice rafting of debris from Antarctica peaked from 6.6 to $6.1 \mathrm{Ma}$, apparently as a result of advances of Antarctic glaciers and ice shelves (34), and glaciation in Patagonia is reported to have taken place around 6 to $7 \mathrm{Ma}$ (35).

Taken together, there is considerable evidence that significant global climate variability during the Late Miocene led to a growth of glaciers. Glaciers would readily form in southeast Greenland because of the combination of high precipitation and high topography in the area, and North Atlantic glaciation likely nucleated in this region rather than further north.

Our new data add considerable constraints to the long-term modeling of North Atlantic glaciation. Consistent with data from Iceland (36), they prove that the Middle Miocene was fairly mild, that cooling most likely started shortly after $10 \mathrm{Ma}$ within the early Late Miocene, and that full glacial conditions in southeast Greenland were established around $7 \mathrm{Ma}$ in the middle Late Miocene, contemporaneous with Southern Hemisphere glacial expansion. The Late Miocene and Pliocene climate was variable, with perhaps completely ice-free periods. North Atlantic glaciation may have nucleated in-and for the first million years, been largely restricted to-Greenland. The east-west gradient in the abundance of glacial material off southeast Greenland makes it unlikely that this part of Greenland has provided significant contributions to the northern North Atlantic IRD found elsewhere. Therefore, IRD from off mid-Norway and Svalbard dated to between 5.7 and $4.5 \mathrm{Ma}(8,23)$ suggests that other North Atlantic ice sheets started to form no later than that time and that they were fully established at about 2.5 Ma.

\section{References and Notes}

I. C. U. Hammer, in The Environmental Record in Glaciers and Ice Sheets, D. Donferenzen, $\mathrm{H}$. Oeschger, C. C. Langway, Eds. (Wiley, New York, 1989), pp. 99-I2I.

2. S. Funder, in Quaternary Geology of Canada and Greenland, R. J. Fulton, Ed. (Geological Society of America, Denver, CO, 1989), Pp. 756-763.

3. R.W. Feyling-Hanssen et al., Geol. Soc. Den. Bull. 3I, 81 (1983).

4. I. McDougall and H.Wensink, Earth Planet. Sci. Lett. I, 232 (1966).

5. K. J. Albertsson, Natturufraedingurinn 48, I (1978).

6. N. J. Shackleton et al., Nature 307, 620 (1984).

7.W. F. Ruddiman and M. E. Raymo, Philos. Trans. R. Soc. London 3 I 8, 4 I I (1988).

8. E. Jansen, J. Sjøholm, U. Bleil, J. A. Erichsen, in Geological History of the Polar Oceans: Arctic Versus Antarctic, U. Bleil and J. Thiede, Eds. (Kluwer, Amsterdam, 1990), Pp. 677-705.

9. N. Reeh, in Quaternary Geology of Canada and Greenland, R. J. Fulton, Ed. (Geological Society of America, Denver, CO, 1989), Pp. 795-822.

I0. G. Bond et al., Nature 360, 245 (1992).

I I.A. D. Miall, Sedimentology 32, 763 (1985).

12. D. Bridgewater et al., in Geology of Greenland, A. Escher and W. S. Watt, Eds. (Grønlands Geologiske Undersøgelse, Copenhagen, 1976), pp. 18-75

I3. T. F. D. Nielsen et al., Rapp. Grønlands Geol. Undersøgelse I48, 93 (1990)

I4. B. G. J. Upton et al., J. Petrol. 25, I5 I (1984).

15. H. C. Larsen, in The Arctic Region, A. Crantz, L. Johnson, J. F. Sweeney, Eds. (Geological Society of America, Denver, CO, 1990), Pp. I85-210.

16. N. Henriksen and A. K. Higgins, in Geology of Greenland, A. Escher and W. S. Watt, Eds. (Grønlands Geologiske Undersøgelse, Copenhagen, 1976), pp. I82-246.

17. B. F. Molnia, in Glacial-Marine Sedimentation, B. Molnia, Ed. (Plenum, New York, 1983), pp. 593-626.

18. The continental shelf in East Greenland is primarily a constructional glacial feature and appears to be a prototypical example of the glacial-shelf sedimentation model described by G. S. Boulton, in "Glacimarine Environments: Processes and Sediments," J. A. Dowdeswell and J. D. Sourse, Eds., Geol. Soc. London Spec. Publ. 53 (1990), pp. I 542.

19.W. F. Ruddiman and A. Mclntyre, Geol. Soc. Am. Mem. I45, III (1976).

20. H. Zimmerman et al., Init. Rep. Deep Sea Drill. Proj. 81, 86 I (1985).

21 . The last occurrence of Discoaster quinqueramus (nannofossil) is correlated with the middle of magnetic chron $\mathrm{C} 3 r$ at middle latitudes [see S. Monechi et al., ibid. 86, 787 (1985)], with an age of $5.5 \mathrm{Ma}$ in the time scale of Cande and Kent [J. Geophys. Res. 97, 13917 (1992)]. The age at site 918 may be older because discoasters, which preferred warm waters, invariably disappeared earlier at higher latitudes.

22. The change from dominantly dextral to dominantly sinistral coiling in Neogloboquadrina atlantic has been correlated with magnetic chron $\mathrm{C} 3 \mathrm{Ar}$ at high and middle latitudes [D. Spiegler and E. Jensen, Proc. Ocean Drill. Prog. Sci. Res. I04, 68I (1989)], with an age around $6.6 \mathrm{Ma}$ in the time scale of Cande and Kent (20).

23. The earliest IRD at ODP site 645 in Baffin Bay west of Greenland appears in Late Miocene sediments [M. Cremer, Proc. Ocean Drill. Prog. I05, 7 (1989)]. At site 646 south of Greenland, IRD is known from 5.7 Ma and is in abundance from $4.0 \mathrm{Ma}$ [T. C. W. Wolf and J. Thiede, Mar. Geol. I0I, 83 (199I)]. Similarly, at ODP site 642 in the Norwegian Sea east of Greenland, the first IRD appears as early as $5.4 \mathrm{Ma}$ [E. Jansen et al., Proc. Ocean Drill. Prog. Sci. Res. I 04, 255 (1989)].

24. L. Keigwin, Init. Rep. Deep Sea Drill Proj. 94, 9II (1986).

25. S. Funder, in Quaternary Geology of Canada and Greenland, R. J. Fulton, Ed. (Geological Society of America, Denver, CO, 1989), Pp. 763-769.

26. S. Funder et al., Grønlands Geol. Undersøgelse I 20, 9 (1984).

27. D. F. Williams, in Sea-Level Changes: An Integrated Approach, C. K.Wilgus et al., Eds. (Society of Economic Paleontologists and Mineralogists, Tulsa, OK, 1988), pp. 31-37.

28. K. G. Miller and R. G. Fairbanks, S. Afr. J. Sci. 8I, 248 (1985)

29. B. U. Haq et al., in Sea-Level Changes: An Integrated Approach, C. K.Wilgus et al., Eds. (Society of Economic Paleontologists and Mineralogists, Tulsa, OK, 1988), pp. 7I-108.

30. B. U. Haq et al., Science 235, I I 56 ( I 987).

3I. R. G. Fairbanks and R. K. Mathews, Quat. Res. I0, I8I (1978).

32. J. M. Armentrout, in Geology of Greenland, A. Escher and W. S. Watt, Eds. (Grønlands Geologiske Undersøgelse, Copenhagen, 1976), pp. 629-666.

33. J. A. Barron and G. Keller, Micropaleontology 29, 150 (1983).

34.W. U. Ehrmann etal., in "Synthesis of Results from Scientific Drilling in the Indian Ocean," Am. Geophys. Union Geophys. Monogr. Book Ser 70 (1992), pp. 423-446.

35. J. H. Mercer and J. F. Sutter, Palaeogeogr. Paleoclimatol. Palaeoecol. 38, I85 (1982).

36.W. L. Friedrich and L.A. Simonarson, Palaeontographica 182, I5I (1982). 